\title{
The effect of chemical composition on the leaching behaviour of electric arc furnace (EAF) carbon steel slag during a standard leaching test
}

\author{
D. Mombelli ${ }^{a}, *$, C. Mapelli ${ }^{\mathrm{a}}$, S. Barella ${ }^{\mathrm{a}}$, C. Di Cecca ${ }^{\mathrm{a}}$, G. Le Saout ${ }^{\mathrm{b}}$, E. Garcia-Diaz $^{\mathrm{b}}$ \\ a Dipartimento di Meccanica, Politecnico Di Milano, Via La Masa 1, Milano 20156, Italy \\ b Centre des Matériaux des Mines d'Alès (C2MA), Ecole des Mines d'Alès (Institut Mines Telecom), Avenue de Clavières 6, 30100 Alès cedex, France
}

\begin{abstract}
A B S T R A C T
The electric arc furnace (EAF) slag could be exploited in several fields of application, such as land filling, road constructions and concrete production. However, their use is limited by the presence of polluting chemical elements (chromium $(\mathrm{Cr})$, barium $(\mathrm{Ba})$, Vanadium $(\mathrm{V})$, etc.) that can be dangerous to humans and the environment. Thus, chemical and structural stability is a fundamental requirement, especially when the slag may come in contact with water. Therefore, the interaction between slag and water is key, in order to classify the slag as a safe raw material. In this work, the effect of slag chemical composition on the chemical leaching of about seventy EAF carbon steel slags of different production steel grades was investigated. Standard leaching tests $(24 \mathrm{~h}$ at $10 \mathrm{l} / \mathrm{kg}$ ) in deionized water on slag bulks were performed and the results were correlated with the slag chemical composition. The survey has made possible defining the safe chemical composition areas on the main ternary diagrams, able to transfer stability to the slag. The results obtained indicate the water/slag ratio as the most important factor in the release of polluting substances, also identifying a critical scenario for slag recycling.
\end{abstract}

Keywords:

Electric arc furnace (EAF) slag

Leaching behaviour

Standard leaching test

Chemical composition

Ternary diagrams

\section{Introduction}

Steel slags are today largely utilized in roads, as construction and paving materials, since their physical properties are similar, or sometimes better, than natural materials like gravel.

Environmental concerns regarding utilization and landfilling of steel slags focused on the content of heavy metals and particularly on the leachable quantities, where chromium $(\mathrm{Cr})$ has gained special attention due to its toxicity in the hexavalent state [1,2]. Other chemical species, i.e. barium (Ba), vanadium (V), molybdenum (Mo), require monitoring due to their high toxicity on humans and the environment $[3,4]$. The identification of leaching behaviour is mandatory for slag use in unbound applications, i.e. unpaved roads, armourstone or gabions, because in such conditions, slag is subject to a continuous cycle of wetting and drying. Several studies [5-9] have investigated the leaching behaviour of slag aggregates, and highlight that such aggregates could potentially release dangerous chemical elements (especially $\mathrm{Ba}, \mathrm{V}$ and $\mathrm{Cr}$ ), as well as unbound slag, when coming into contact with water. In

\footnotetext{
* Corresponding author.

E-mail address: davide.mombelli@polimi.it (D. Mombelli).
}

particular, the recycling of such a slag is subordinated with respect to the severe limits imposed by national legislative decrees that change from country to country in European Union. Also the list of substances and chemicals to be monitored changes from country to country. For examples, Italian environmental legislation requires the monitoring of 22 parameters, namely $\mathrm{pH}, \mathrm{COD}, \mathrm{As}$, $\mathrm{Ba}, \mathrm{Be}, \mathrm{Cd}, \mathrm{Co}, \mathrm{Cr}$ (tot), $\mathrm{Cu}, \mathrm{Hg}, \mathrm{Mo}, \mathrm{Ni}, \mathrm{Pb}, \mathrm{Sb}, \mathrm{Se}, \mathrm{V}, \mathrm{Zn}, \mathrm{Cl}^{-}, \mathrm{CN}^{-}, \mathrm{F}^{-}$, $\mathrm{NO}_{3}{ }^{-}, \mathrm{SO}_{4}{ }^{2-}$, whereas in Germany only few parameters must be controlled (pH, EC, Cr, Mo, V and Fluorides). In France and Spain almost the same elements are restricted (particularly focused on heavy metals). The limits on $\mathrm{Cd}$ and Se in Spain are the most strictly (less than $1 \mu \mathrm{g} / \mathrm{l}$ ) amongst the considered European countries. Moreover, German legislation does not require any control on $\mathrm{Ba}$ leaching, whereas the Ba limits in France and Spain are twice the level of Italian limits. Also the $\mathrm{V}$ is considered differently in the various EU countries: severe limits are set in Italy, Germany and Spain, but not in France [10-15].

To determine the concentration of leached elements every country adopts a different test criteria that contributes to confusion about slag environmental safety (Table 1), in spite of the European Committee of Standardization (CEN) is considering the introduction of common harmonized standards $[16,17]$. 
Table 1

Environmental legislation and leaching test standards for different European countries.

\begin{tabular}{|c|c|c|c|c|c|}
\hline Country & Italy & Germany & & France & Spain (Basque Country) \\
\hline Environmental legislation & DLGS 152-2006 & EBV & TL Gestein StB 04 & $\begin{array}{l}\text { SETRA } \\
\text { Guide de laitiers sidérurgique }\end{array}$ & $\begin{array}{l}\text { RD 34/2003 } \\
\text { RD 49/2009 }\end{array}$ \\
\hline Leaching test standard & EN12457-2 & $\begin{array}{l}\text { DIN19528 } \\
\text { DIN19529 }\end{array}$ & DIN38414-4 & EN12457-4 & EN12457-3 \\
\hline $\mathrm{L} / \mathrm{S}$ ratio & $10 \mathrm{l} / \mathrm{kg}$ & $21 / \mathrm{kg}$ & $10 \mathrm{l} / \mathrm{kg}$ & $10 \mathrm{l} / \mathrm{kg}$ & $\begin{array}{l}\text { First step } 21 / \mathrm{kg} \\
\text { Second step } 8 \mathrm{l} / \mathrm{kg}\end{array}$ \\
\hline Sample granulometry & $<4 \mathrm{~mm}$ & $<32 \mathrm{~mm}$ & $<32 \mathrm{~mm}$ or $8-11 \mathrm{~mm}$ & $<10 \mathrm{~mm}$ & $<4 \mathrm{~mm}$ \\
\hline Test duration & $24 \mathrm{~h}$ & $24 \mathrm{~h}$ & $24 \mathrm{~h}$ & $24 \mathrm{~h}$ & $\begin{array}{l}\text { First step } 6 \mathrm{~h} \\
\text { Second step } 18 \mathrm{~h}\end{array}$ \\
\hline
\end{tabular}

In this study, the Italian regulation was taken as reference since very critical test criteria are adopted, with high liquid-to-solid ratio (L/S) coupled with a small aggregate size that could enhance the leaching of such a chemicals.

Even if the conditions under which the leachates are produced vary as a result of different physical parameters like $\mathrm{pH}$, temperature, or flow conditions, and influence the resulting concentrations of metals in the leachates [18], the slag chemical composition covers an important role on immobilization, or the release of the above mentioned toxic elements. For example, $\mathrm{MgO}$ concentration in the slag seems to be favourable for $\mathrm{Cr}$ immobilization but detrimental for the leaching of other polluting elements, i.e. Ba and V [19]. The solution behaviour of these elements have a parabolic law as a function of $\mathrm{CaO}$ and $\mathrm{MgO}$ concentration, whereas their dependence on silica concentration is generally described by a linear law [20]. Currently, the role of chemical composition on carbon steel slag leaching behaviour has not been extensively and systematically investigated, and is often only dedicated to $\mathrm{Cr}$ leaching [21,22]. For these reasons, an in-depth understanding of the role of the average chemical composition on slag leaching behaviour in standard conditions (deionized water at $\mathrm{pH} 7$, room temperature, L/S: 101/ $\mathrm{kg}$ ) could give important indications to steelmakers about how to properly manage or modify their slag to improve their environmental sustainability and recycling.

In this study, different classes of carbon steel EAF slag from different steel productions (reinforced bar steel, high alloyed steel and quality steel) were investigated, in order to correlate their leaching behaviour in standard conditions with chemical features. The main goal of the present work is to forecast the leaching behaviour of a slag by average chemical composition, and define a corrective path to transform slag into a safe by-product. Chemical composition and slag-water interaction were investigated and correlated with the results of standard leaching tests (in accordance with EN 12,457-2) performed on bulk slag $4 \mathrm{~mm}$ in size. The effects of the main chemical species ( $\mathrm{CaO}, \mathrm{MgO}$, $\mathrm{Al}_{2} \mathrm{O}_{3}, \ldots$ ) on $\mathrm{Ba}, \mathrm{Cr}$ and $\mathrm{V}$ leaching is discussed. To better understand how the slag interacts with water during standard leaching tests, qualitative tests were performed on $4 \mathrm{~mm}$ of crushed slag grains at different $\mathrm{L} / \mathrm{S}$ ratios (10 and $100 \mathrm{l} / \mathrm{kg}$ ). The analyses allowed for the identification of safe chemical composition areas on the main ternary diagrams that ensure full slag stability.

Table 2

Slag classification and number of samples according to chemical composition and steel grades.

\begin{tabular}{lllll}
\hline Group ID & No. of samples & $\mathrm{FeO}_{x}$ & $\mathrm{Cr}_{2} \mathrm{O}_{3}$ & Production \\
\hline $\mathrm{A}$ & 13 & $>25 \%$ & $<5 \%$ & Reinforcing bar steel \\
$\mathrm{B}$ & 10 & $>25 \%$ & $>5 \%$ & High alloyed steel \\
$\mathrm{C}$ & 46 & $<25 \%$ & $<5 \%$ & Quality steel \\
\hline
\end{tabular}

\section{Experimental procedure}

The EAF slags were provided by different Italian and European electric steelworks and associated with different steel productions. Sixty-nine different samples were collected and investigated, classifying the different slag into three groups according to the amount of iron and chromium oxide (Table 2). The number of samples for each group is indicated in Table 2.

The slag chemical composition was determined by ED-XRF analysis through the Ametec Spectro Xepos spectrometer in He atmosphere on $5 \mathrm{~g}$ of powdered slag.

The average chemical composition of the slag is reported in Table 3, and their position on ternary diagrams is shown in Fig. 1.

A morphological and microstructural investigation was performed by means of XRD and SEM analyses.

X-ray diffraction (XRD) data were collected using a Bruker D8 Advance diffractometer in a $\theta-\theta$ configuration employing the $\mathrm{Cu}$ $K \alpha$ radiation $\left(l=1.54 \AA\right.$ ) with a fixed divergence slit size $0.5^{\circ}$ and a rotating sample stage. Grinded samples (average diameter $15 \mu \mathrm{m}$ ) were scanned between 10 and $80^{\circ}$ (step size of $0.007^{\circ}$ ) with the Vantec detector.

The morphological and microstructural characterization was performed by Zeiss EVO50 scanning electron microscopy (SEM) equipped with an Oxford Inca EDS probe. The slag was moulded in araldite-based resin, before being ground and polished.

Standard leaching tests were performed according to EN $12,457-2$ on granulated slag ranged from 4 to $0.1 \mathrm{~mm}$. The fine fraction below $0.1 \mathrm{~mm}$ was discharged. The slag test portion was brought in contact with fixed volume of deionized water $(10 \mathrm{l} / \mathrm{kg})$ and stirred at $10 \mathrm{rpm}$ by a rotatory mixer for $24 \mathrm{~h}$. The test is based on the assumption that equilibrium or near-equilibrium is achieved between the liquid and solid phases during the test. The concentration limits taken as a reference are indicated in the Italian legislative decrees (D.M. 03 August 2005 N. 201 [10] and D. M. 05 April 2006 N. 186 [11]). Leached concentrations were measured by ICP-OES (induced coupled plasma-optical emission spectroscopy, detection limit $30 \mu \mathrm{g} / \mathrm{l}$ ).

To investigate slag-water interaction, a crushed particle (approximately $4 \mathrm{~mm}$ in size) for every slag was leached as a standard leaching test required but varying the $\mathrm{L} / \mathrm{S}$ ratio $(10,100 \mathrm{l} /$ $\mathrm{kg})$. Slags were characterized by SEM, before and after elution tests, to detect morphological alterations, and to make a qualitative comparison on the effects caused by water erosion. The same

Table 3

Chemical composition range (min-max) of the investigated slag (\% weight).

\begin{tabular}{llllllccl}
\hline Group ID & $\mathrm{MgO}$ & $\mathrm{Al}_{2} \mathrm{O}_{3}$ & $\mathrm{SiO}_{2}$ & $\mathrm{CaO}$ & $\mathrm{FeO}_{x}$ & $\mathrm{Cr}_{2} \mathrm{O}_{3}$ & $\mathrm{~V}_{2} \mathrm{O}_{5}$ & $\mathrm{Ba}$ \\
\hline A & $2-5$ & $10-15$ & $15-20$ & $15-25$ & $30-50$ & $2-5$ & $0.1-0.2$ & $0.05-$ \\
& & & & & & & & 0.1 \\
$\mathrm{~B}$ & $1-3$ & $1-3$ & $5-25$ & $15-25$ & $30-50$ & $5-30$ & $1-2$ & $\mathrm{ND}$ \\
$\mathrm{C}$ & $5-15$ & $5-15$ & $10-40$ & $20-50$ & $5-30$ & $0.5-5$ & $0.05-0.4$ & $0.1-0.5$ \\
\hline
\end{tabular}



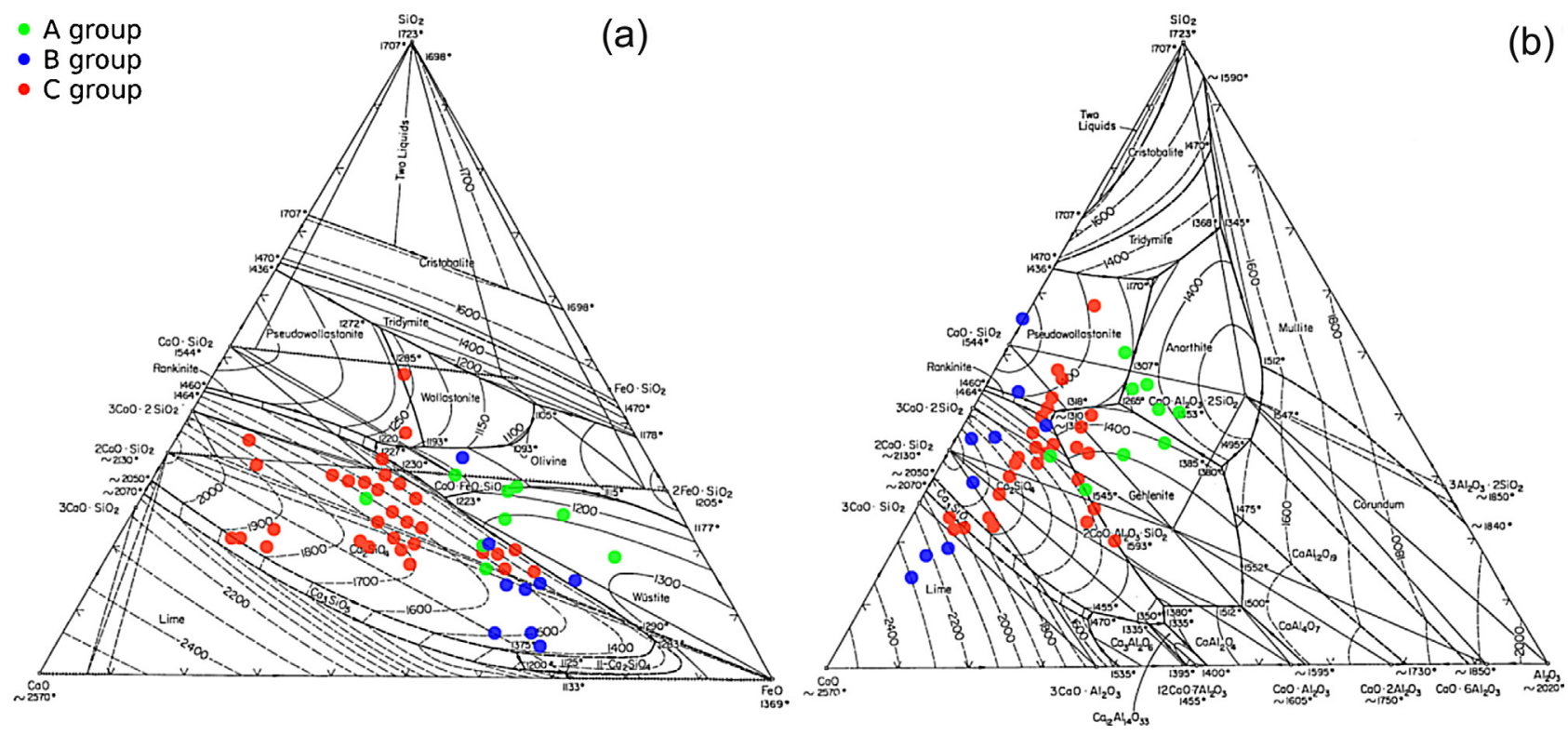

Fig. 1. Sample identification on (a) $\mathrm{CaO}-\mathrm{SiO}_{2}-\mathrm{FeO}$ and (b) $\mathrm{CaO}-\mathrm{Al}_{2} \mathrm{O}_{3}-\mathrm{SiO}_{2}$ phase diagram [23]. Some points overlap.
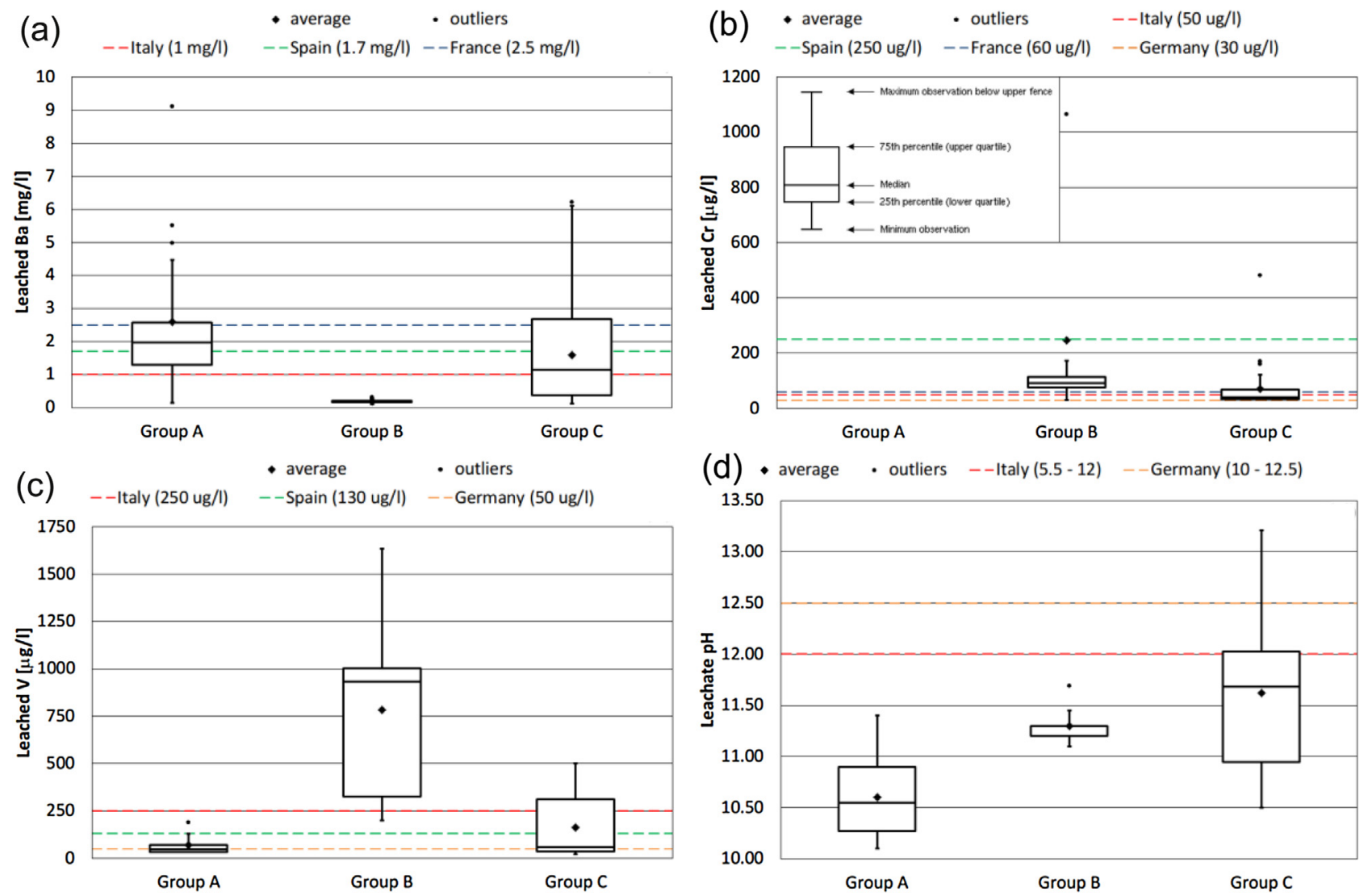

(d) - average $\cdot$ outliers --Italy $(5.5-12) \quad--$ Germany $(10-12.5)$

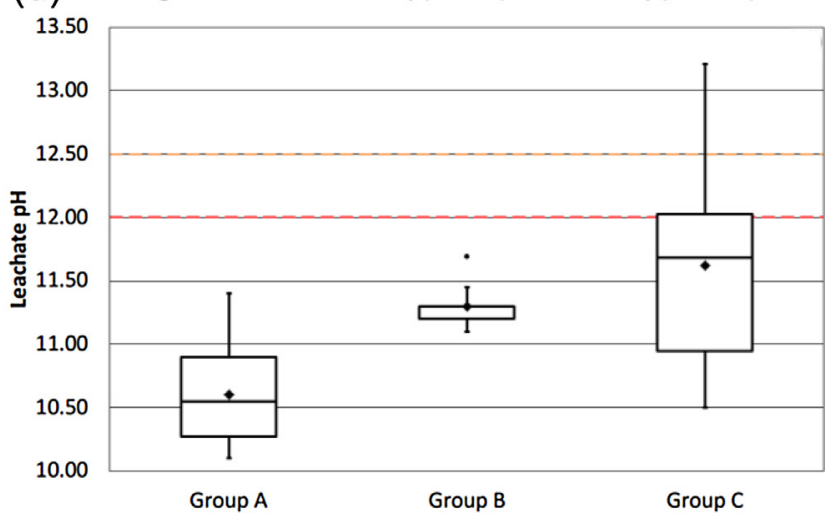

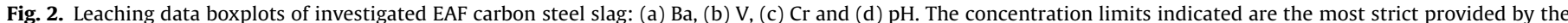
different environmental laws applied in the different countries. 

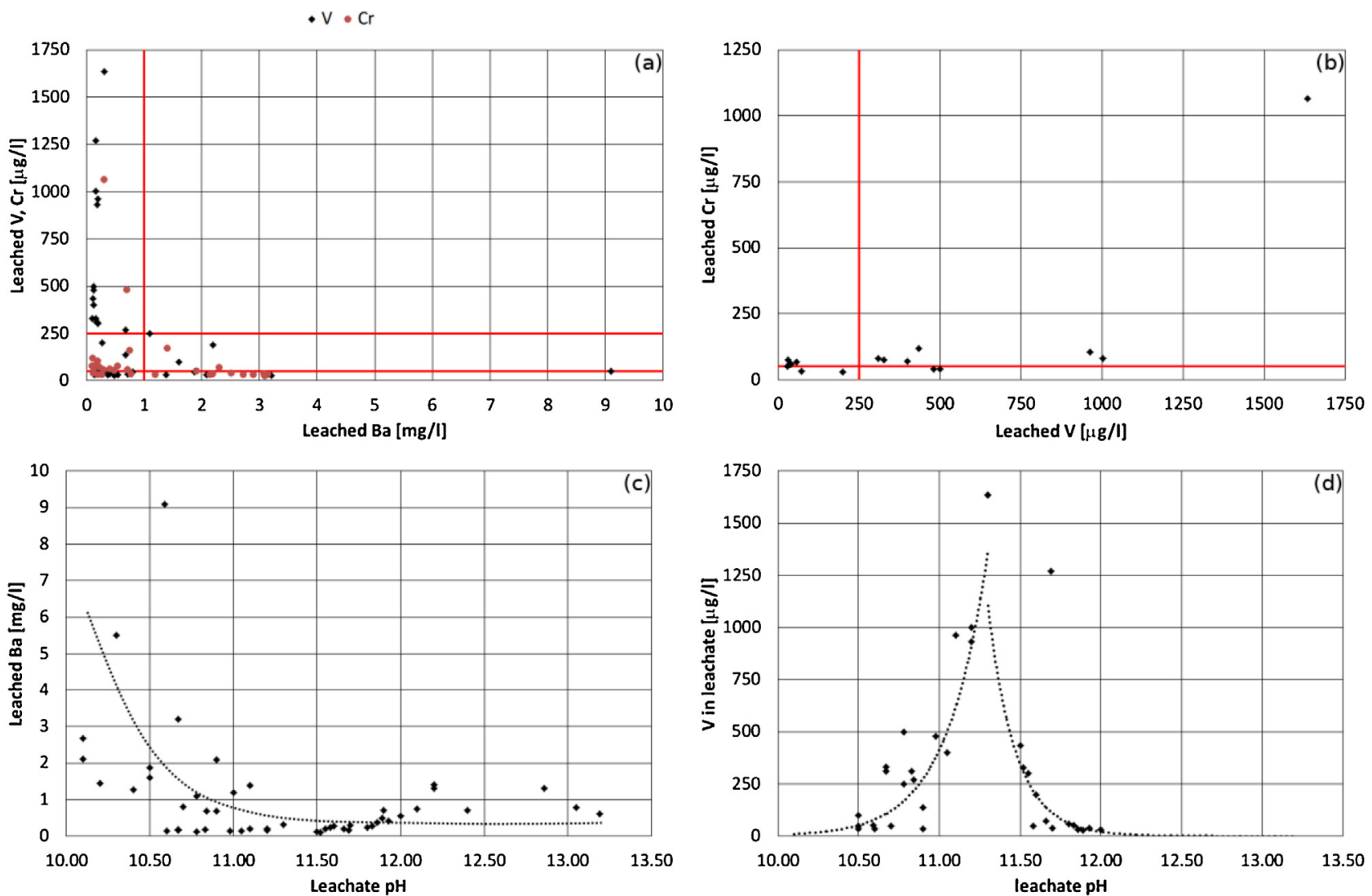

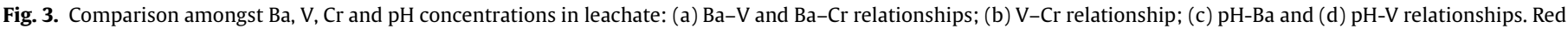

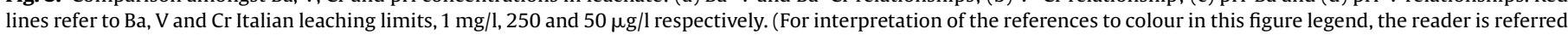
to the web version of this article.)

particle was repeatedly treated at the different $\mathrm{L} / \mathrm{S}$ ratio and the same area was analysed after each condition.

\section{Results and discussion}

Chemical, crystallographic and microstructural characterizations

Other differences, with respect to the first classification, can be highlighted amongst the different slag typologies. In fact, slag from the reinforcing bar steel production (group A) is characterized by high iron (averagely $40 \%$ wt.) and aluminium oxide (above $10 \% \mathrm{wt}$.) content (Table 3 ). High oxygen flow is required during steel production due to the high heterogeneity of the scrap used, in terms of size and chemical composition and the high content of polluting elements.

The slags belonging to group $\mathrm{B}$ are generally typified by a low content of $\mathrm{MgO}$ and $\mathrm{Al}_{2} \mathrm{O}_{3}$ (less than 3\% wt.), and by a high fraction of $\mathrm{Cr}, \mathrm{V}$ and Mo oxides, derived from both the high alloyed scrap used during manufacturing and from the ferro-alloys additions during the refining (Table 3 ).

The slag associated to quality steels (group C) is mainly formed by $\mathrm{CaO}$ (sometimes over the $50 \%$ wt.) and a small quantity of $\mathrm{FeO}$ (limited oxidation of the steel scraps to limit the FeO around 15$20 \%$ wt.) (Table 3 ). Quality steels require a very low $P$ and $S$ content, and therefore a large amount of $\mathrm{CaO}$ is necessary to maintain high slag activity.

Despite of the significant differences in chemical composition, crystallographic and microstructural analysis of the investigated slag highlighted the occurrence of five main phases ${ }^{1}$ [24-36]: wustite, ( $\mathrm{Mg}, \mathrm{Cr}, \mathrm{Fe}, \mathrm{Al}$ )-spinel, bredigite and/or larnite, brownmillerite, gehlenite.

Other phases, like kirschsteinite, were detected, generally in a sample featuring high $\mathrm{FeO}$ content and a moderate $\mathrm{MgO}$ fraction (group A and B), whereas merwinite is formed in slag with high levels of $\mathrm{MgO}$ and $\mathrm{CaO}$ (group $\mathrm{C}$ ). Slags belonging to group $\mathrm{C}$ were also characterized by a small fraction of tri-calcium silicate and free lime, since these samples are characterized by the highest $\mathrm{CaO}$ content that cannot be completely complexed by $\mathrm{SiO}_{2}$. In two samples (one belonging to group $\mathrm{B}$ and one to group $\mathrm{C}$ ) the XRD pattern pointed out a particularly intense peak associated to $\mathrm{Ca}$ chromite.

The role played by these crystalline phases during leaching tests is discussed in detail in the following paragraphs.

\section{Standard leaching test results}

Standard leaching test results, performed according to EN $12,457-2$, on slag particles ranged from 4 to $0.1 \mathrm{~mm}$ highlight that carbon steel EAF slag manifest only $\mathrm{Ba}, \mathrm{V}$ and $\mathrm{Cr}$ leaching, whereas the other species were always under the regulatory limits [37]. These results were observed also in previous experiments [38-40] and for this reason only $\mathrm{Ba}, \mathrm{Cr}$ and $\mathrm{V}$ behaviour were discussed. The $\mathrm{Ba}, \mathrm{V}$ and $\mathrm{Cr}$ mean and median values surpassed not only the maximum Italian concentration permitted, but also, in some cases,

\footnotetext{
1 Refer to "LIST OF PHASES" for the chemical formula
} 
those imposed by the other European countries [12-15] (Fig. 2). Group A slag only seemed to be problematic for Ba, whereas V and $\mathrm{Cr}$ values are always far enough from regulation limits (Fig. 2a). Group B was mainly characterized by $\mathrm{V}$ leaching even if some samples also induced $\mathrm{Cr}$ leaching (Fig. 2b). Group $\mathrm{C}$ slag showed $\mathrm{Ba}$ and $\mathrm{Cr}$ release, whereas $\mathrm{V}$, in most of the samples, complied with the limit, even if all the vanadium content characterizing the steel scraps is absorbed by the slag in oxidized form (Fig. 2c). Even if $\mathrm{V}$ does not seem problematic for this last slag group, the detection of high $\mathrm{V}$ concentration released by some samples does not exclude $\mathrm{V}$ leaching for this kind of slag. This result indicates that $\mathrm{Cr}$ release is always associated to the release of other elements, namely $\mathrm{V}$, whereas Ba leaching can occur with or without the leaching of other substances (Fig. 3). Moreover, Ba and $\mathrm{Cr}$ leaching seems to interest carbon steel slag the most (A and C groups), and $\mathrm{V}$ leaching is only prevalent in high alloyed steel slag (B group).

Some outliers were identified for $\mathrm{Ba}$ and $\mathrm{Cr}$. In the first case, three samples of group A released an unexpected high concentration of Ba. Currently, no explanations have been found, since the microstructure of those samples did not indicate particular phases or unusual configurations. This behaviour could depend on the high $\mathrm{MgO}$ content and will be discussed in the next paragraphs. The outlier samples that leached an unexpected concentration of $\mathrm{Cr}$ belong to group B and group C, respectively. The samples are those featured by Ca-chromite and this phase is probably the main phase involved in $\mathrm{Cr}$ leaching.

The leachate $\mathrm{pH}$ complied with the safety range proposed by the regulation in most of the analysed samples, and its average values increase in a linear form from group A to group $\mathrm{C}$, and is probably due to the different content of $\mathrm{CaO}$ and $\mathrm{FeO}$ in the slag (Fig. 2d). Leachate from group $\mathrm{C}$ reached the highest $\mathrm{pH}$ values and in some cases surpassed the maximum admitted value $(12 \mathrm{pH})$. Over that value the environment becomes caustic and must be classified as corrosive, further limiting the possibility to use steel slag for civil purposes [41].

Ba concentration was high in leachates featured by low $\mathrm{pH}$ numbers. $\mathrm{Ba}$ in the slag is mainly present in the form of $\mathrm{BaO}$ and, since it is an alkaline oxide, it tends to dissolve first in water together with the other alkaline elements. However, if the environment reaches alkaline $\mathrm{pH}$, the $\mathrm{BaO}$ migration should be reduced [42]. This hypothesis is consistent with the experimental evidence (Fig. 3c) and should explain the low Ba concentrations when the leachate reached high pH values (between 11 and 13).

Vanadium oxide is considered an amphoteric species $[43,44]$ and in alkaline solutions tends to behave as acid oxide [45]. Since the EAF slag is basic slag, the leachate produced from their dissolution generally reach a $\mathrm{pH}$ in the range $11-13$. This could explain the high concentration of such elements in leachate having a $\mathrm{pH}$ in the range 11-11.5 [46]. However, when the $\mathrm{pH}$ reaches very high values (above 12), the solubility of $\mathrm{V}$ can be drastically reduced (Fig. 3d).

$\mathrm{Ba}$ and $\mathrm{V}$ seem to have an opposite tendency when dissolved in water (Fig. 3a). Firstly, no samples manifested $\mathrm{Ba}$ and V concentration over the imposed limits in the leachate at the same time. In fact, in all samples with Ba leaching, $\mathrm{V}$ complies with the limits, and vice versa. This behaviour could depend on, and contemporary control, the final leachate $\mathrm{pH}$ and should be ruled by slag chemical composition and phase distribution. In the graph in Fig. 3, it is possible to note some slag fall in the "safe area" (confined between $\mathrm{V}$ and $\mathrm{Ba}$ regulation limits). Those slags are generally characterized by a crystalline gehlenite microstructure that traps and inhibits chemical leaching, due to poor hydraulic properties [47-50].

These results suggest that the correlation between chemical composition and leaching test results could help identify some common aspects governing the interaction between slag and water. For example, the correlation between $\mathrm{Cr}_{2} \mathrm{O}_{3}$ content in slag and $\mathrm{Cr}$ concentrate in the leachate can be excluded. In fact, $\mathrm{B}$ and $\mathrm{C}$ slag leachates had almost the same average $\mathrm{Cr}$ concentration even if the $\mathrm{Cr}_{2} \mathrm{O}_{3}$ content of the first group is five times more than the latter ones. In addition, the same conclusion can be reached for iron oxide, since different $\mathrm{FeO} / \mathrm{Fe}_{2} \mathrm{O}_{3}$ content featured in the different slag groups.

\section{Leaching test on crushed slag particles}

Different slag belonging to groups A, B and C were investigated, and some examples are reported in Figs. 4 and 5. The same particle was repeatedly treated at the different $\mathrm{L} / \mathrm{S}$ ratio and the same surface was analysed after each test condition. The liquid-to-solid ratio is one of the fundamental factors ruling the interaction between slag and the environment. Its effect is evident: increasing the water volume caused an increase in the amount of dissolved slag (Fig. 4). In fact, in standard conditions, the interaction between water and slag was superficial and is only of interest to a limited portion of the surface particle (Fig. $4 \mathrm{~b}$ ), but by increasing the L/S ratio, the surface of the slag particle appeared to be largely consumed (Fig. 4c). This implies that during the standard test, mass loss is not appreciable, even if the slag-water interaction is enough to change the leachate $\mathrm{pH}$ and drive heavy metal leaching. However, not all the surface reacts with water, but only specific phases that are involved in hydration and dissolution processes. In particular, SEM-EDS analysis on the surface (before and after the test) indicated that the Ca-rich silicates, i.e. larnite and

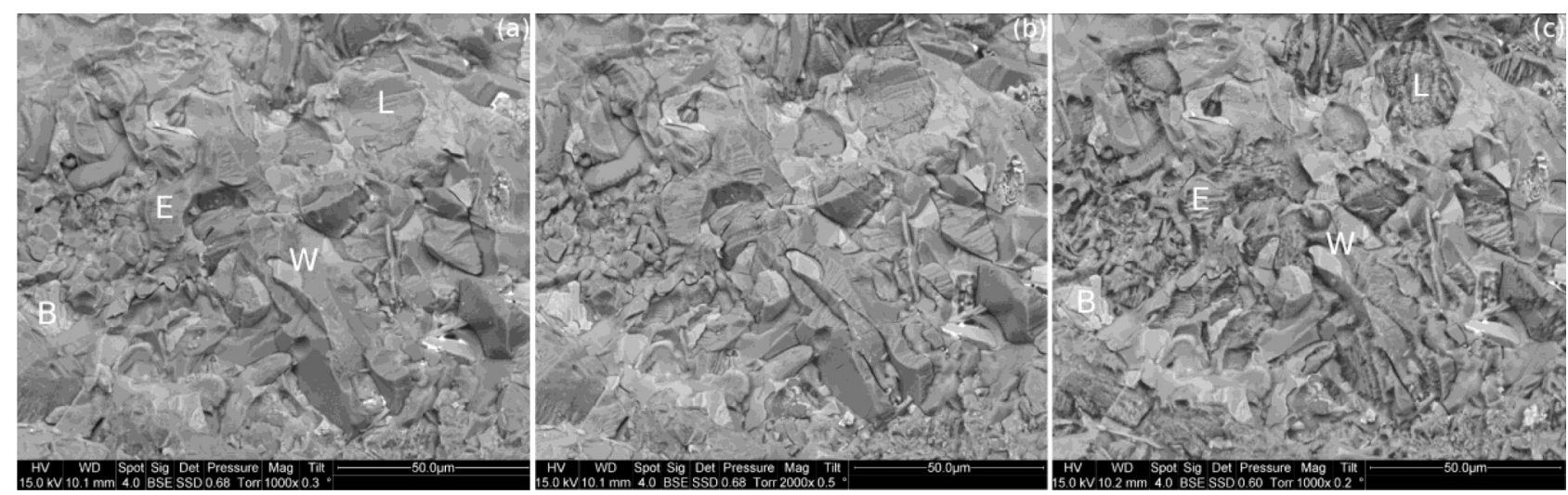

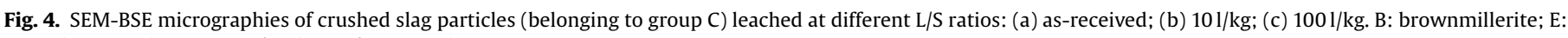
eutectic $3 \mathrm{CaO} \cdot \mathrm{SiO}_{2}-\mathrm{FeO}$; L: larnite and $\mathrm{W}$ : wustite. 

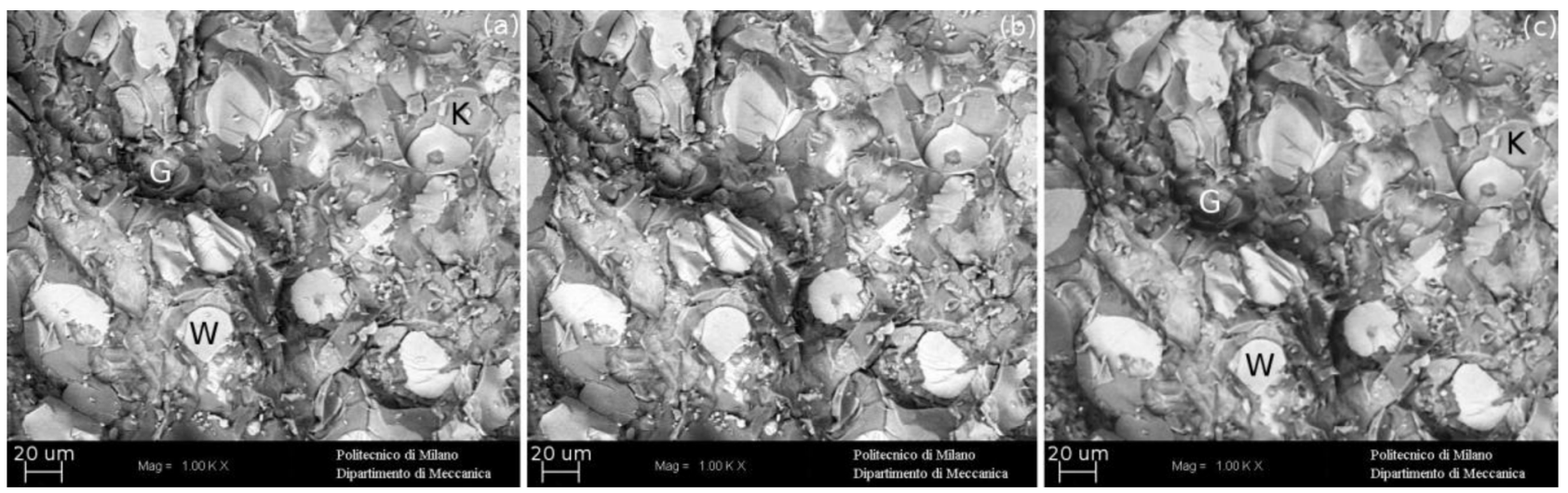

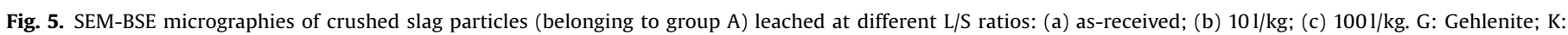
kirschsteinite; W: wustite.

Table 4

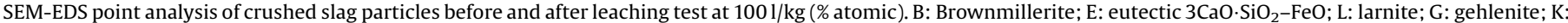
kirschsteinite; W: wustite.

\begin{tabular}{|c|c|c|c|c|c|c|c|c|c|c|c|c|}
\hline Sample & Phase & Condition & $\mathrm{Mg}$ & $\mathrm{Al}$ & $\mathrm{Si}$ & $\mathrm{Ca}$ & $\mathrm{Ti}$ & V & $\mathrm{Cr}$ & Mn & $\mathrm{Fe}$ & $\mathrm{Ba}$ \\
\hline \multirow[t]{8}{*}{ Fig. 4} & \multirow[t]{2}{*}{ W } & Before leaching & 14.27 & & & 19.83 & & & 1.87 & 20.45 & 43.48 & 0.11 \\
\hline & & After leaching $100 \mathrm{l} / \mathrm{kg}$ & 16.30 & & & 18.02 & 0.02 & & 2.11 & 20.15 & 43.39 & 0.01 \\
\hline & \multirow[t]{2}{*}{ E } & Before leaching & & 2.25 & 22.96 & 66.95 & & 0.05 & 0.67 & 2.45 & 4.48 & 0.20 \\
\hline & & After leaching $100 \mathrm{l} / \mathrm{kg}$ & 4.04 & 5.99 & 14.93 & 28.59 & 0.44 & 0.14 & 2.71 & 15.22 & 27.85 & 0.08 \\
\hline & \multirow[t]{2}{*}{ B } & Before leaching & 1.00 & 25.79 & 1.18 & 49.09 & 1.41 & 0.43 & 8.48 & 1.03 & 11.47 & 0.10 \\
\hline & & After leaching $100 \mathrm{l} / \mathrm{kg}$ & 1.03 & 23.28 & 2.46 & 48.45 & 1.60 & 0.36 & 10.50 & 1.53 & 10.79 & \\
\hline & \multirow[t]{2}{*}{$\mathrm{L}$} & Before leaching & & 1.49 & 31.22 & 66.01 & & 0.38 & 0.23 & & 0.50 & 0.17 \\
\hline & & After leaching $100 \mathrm{l} / \mathrm{kg}$ & 3.49 & 4.66 & 4.37 & 29.26 & & & & 5.02 & 53.20 & \\
\hline \multirow[t]{6}{*}{ Fig. 5} & \multirow[t]{2}{*}{ W } & Before leaching & 8.34 & & & & & 0.06 & 1.00 & 9.06 & 81.52 & 0.02 \\
\hline & & After leaching $100 \mathrm{l} / \mathrm{kg}$ & 10.35 & & & 0.43 & & 0.10 & 1.10 & 8.81 & 79.15 & 0.05 \\
\hline & \multirow[t]{2}{*}{ K } & Before leaching & 10.30 & & 39.79 & 36.67 & & & & 3.30 & 9.94 & \\
\hline & & After leaching $100 \mathrm{l} / \mathrm{kg}$ & 12.50 & & 43.69 & 33.72 & & & & 2.32 & 7.70 & 0.07 \\
\hline & \multirow[t]{2}{*}{ G } & Before leaching & 3.28 & 21.98 & 29.86 & 39.78 & & & & 0.66 & 4.44 & \\
\hline & & After leaching $100 \mathrm{l} / \mathrm{kg}$ & 4.25 & 23.08 & 28.53 & 31.34 & & & & 1.40 & 11.38 & 0.01 \\
\hline
\end{tabular}

brownmillerite, drive the slag dissolution (B and L marks in Fig. 4). The dissolved larnite fraction rapidly increases whereas brownmillerite dissolution is clearly evident only at high L/S ratios. Wustite (W) remains unaltered whereas in the complex eutectic phase $3 \mathrm{CaO} \cdot \mathrm{SiO}_{2}-\mathrm{FeO}(\mathrm{E})$ a large amount of $\mathrm{CaO}$ and $\mathrm{SiO}_{2}$ were dissolved, creating a characteristic striped morphology (Table 4). Similar results were obtained for the other slag samples, fully in agreement with those previously reported by other authors [51,52].

However, not all the investigated slag behaved in the same way. For example, the surface of the slag reported in Fig. 5 appeared completely unaltered after immersion at $100 \mathrm{l} / \mathrm{kg}$. This slag complied with leaching limits, thus enabling the possibility to discern between safe and unsafe slag. In this case, the slag microstructure was mainly formed by kirschsteinite ( $\mathrm{K}$ mark in Fig. 5), gehlenite ( $G$ ) and wustite (W) that, as previously stated by the same authors [46], seems to ensure complete stability to the slag. In fact, the particle structure appeared unaltered and the phase chemical composition measured by EDS probe pointed out negligible silicon, calcium and iron dissolution (Table 4).

These results highlight the important role of crystalline phases in slag leaching, as previously stated by several authors $[6,7,33,34,51-54]$. In particular, the stability of wustite was well documented by Belhadj [55], whereas larnite, and its polymorphism bredigite, as well as brownmillerite own hydraulic properties, since they are the same constituents of cement and concrete and behave in the same way when hydrated [36,56,57]. While the microstructure is strictly related to the slag chemical composition, a prediction on the leaching attitude of the slag can be evaluated by coupling chemical information, $\mathrm{CaO}-\mathrm{SiO}_{2}-\mathrm{FeO}_{x}$ and $\mathrm{CaO}-\mathrm{SiO}_{2}-\mathrm{Al}_{2} \mathrm{O}_{3}$ ternary diagrams. In fact, ternary diagrams provide reliable indications about the crystalline phase/phases in the slag matrix. Referring to the samples showed in Figs. 4 and 5, there is an agreement between their position on ternary diagrams, and XRD and SEM evidences.

\section{Discussion}

\section{Barium}

The $\mathrm{MgO}$ concentration in slag controls the Ba leaching with a quadratic equation (Fig. 6a). If a slag contains enough $\mathrm{Mg}$ complexing oxides (i.e. FeO), barium oxide could dissolve in calcium silicates lattice (i.e. $\beta-\mathrm{Ca}_{2} \mathrm{SiO}_{4}$ ). Unfortunately, this phase has hydraulic properties and dissolves during contact with water. In contrast, in high magnesia slag, MgO could replace barium (and calcium) in calcium silicates, reducing the $\mathrm{BaO}$ solubility in such phases (i.e. $\alpha-\mathrm{Ca}_{2} \mathrm{SiO}_{4}$ ) $[58,59]$. Thus, when $\mathrm{Ba}$ is bound in calcium silicates, its release could be enhanced because of the high reactivity of these phases with water. In both cases (with high or low $\mathrm{MgO}$ content), Ba could easily be released. In addition, the $\mathrm{MgO}$ effect could be divided as a function of its average content in the slag. In fact, as indicated in Fig. 7a, two groups can be identified: the first is characterized by $\mathrm{MgO}$ content in the $1-5 \%$ wt. range, the latter from 5 to $14 \%$ wt. The first group consists most prevalently of slag in groups A and B, whereas the latter is mostly in C group slag. 

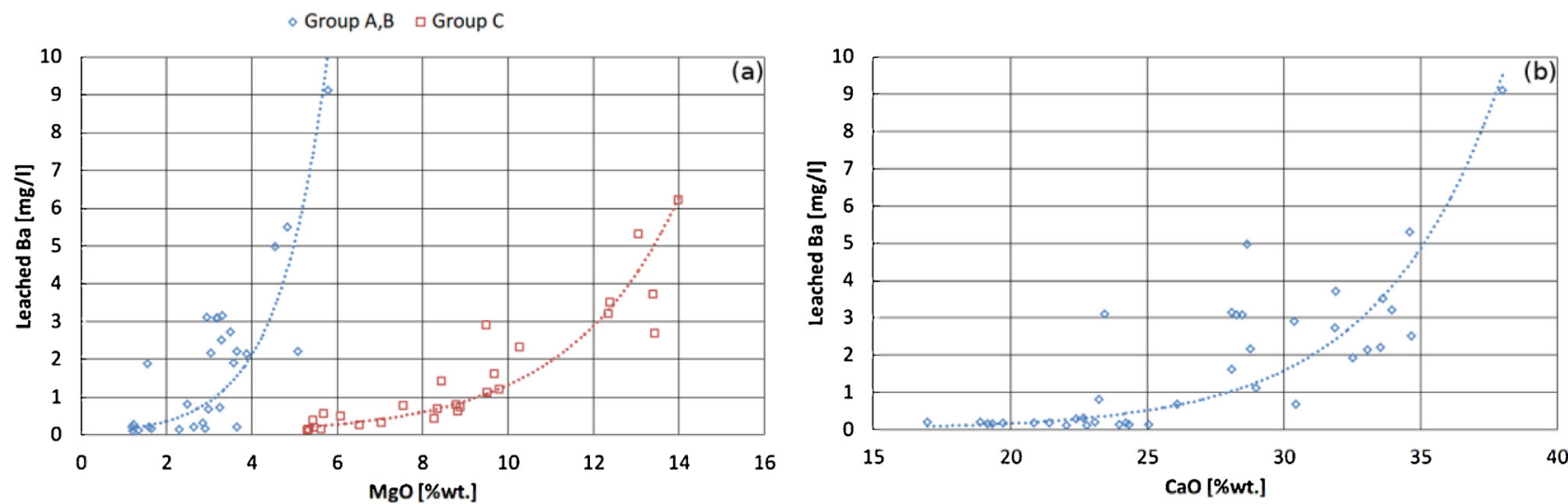

$\circ \mathrm{CaO}[\% \mathrm{wt}.] \quad \square \mathrm{SiO} 2[\% \mathrm{wt}.] \quad \triangle \mathrm{Al} 2 \mathrm{O} 3[\% \mathrm{wt}.] \quad \circ \mathrm{MgO}[\% \mathrm{wt}$.
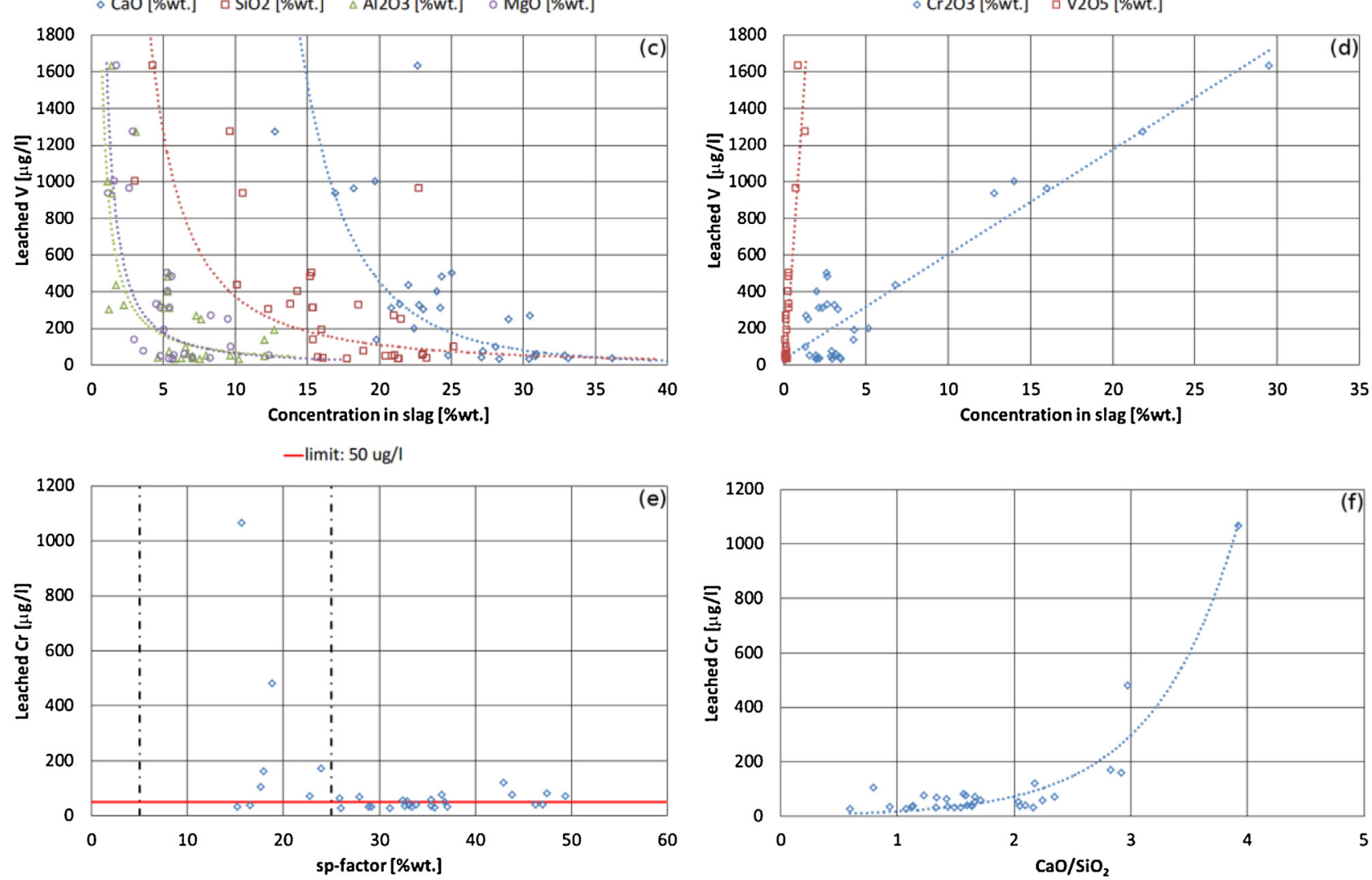

Fig. 6. Effects of slag chemical composition on $\mathrm{Ba}(\mathrm{a}, \mathrm{b}), \mathrm{V}(\mathrm{c}, \mathrm{d})$ and $\mathrm{Cr}(\mathrm{e}, \mathrm{f})$ leaching.

Nevertheless, the $\mathrm{MgO}$ effect on Ba release is the same for both the groups.

The same conclusions can be reached for the $\mathrm{CaO}$ content of the slag. As reported in Fig. 6b, the Ba leaching seems to be favoured by high $\mathrm{CaO}$ concentrations. Most likely, high $\mathrm{CaO}$ content lead to the formation of high-hydraulic silicates that easily react with water (i.e. $\mathrm{Ca}_{3} \mathrm{SiO}_{5}, \mathrm{Ca}_{2} \mathrm{SiO}_{4}$ ). The hydration process facilitates the migration of species such as $\mathrm{Ca}, \mathrm{Mg}$ or $\mathrm{Ba}$ into water.

The effect of $\mathrm{SiO}_{2}$ on slag hydraulic behaviour depends on $\mathrm{CaO}$ content and for this reason no correlation between $\mathrm{SiO}_{2}$ and leached $\mathrm{Ba}$ was found. Thus, $\mathrm{SiO}_{2}$ fraction is not a useful index to forecast slag leaching behaviour, and for this reason is not reported. Although several authors [32-34,46] reported the beneficial effect of the addition of silica on retaining behaviour, in this case, the slag analysed was not chemically treated and the silica content is only related to the process route.
Vanadium

$\mathrm{V}$ behaviour (Fig. $6 \mathrm{c}$ ) seemed to be controlled by $\mathrm{CaO}, \mathrm{SiO}_{2}$, $\mathrm{Al}_{2} \mathrm{O}_{3}$ and $\mathrm{MgO}$ content in the slag. The higher the $\mathrm{CaO}$ fraction the lower $\mathrm{V}$ concentration there is in the leachate. This result complies with the $\mathrm{V}-\mathrm{pH}$ relationship and correlates with other research in the same field. Specifically, some yet to be published results have suggested an experimental correlation between $\mathrm{Ca}$ and $\mathrm{V}$. Increasing the $\mathrm{Ca}$ leaching, $\mathrm{V}$ concentration in the leachate solution slightly decreases. $\mathrm{V}$ also seemed to have a logarithmic dependence on the aluminium and magnesium oxide weight fractions. A direct correlation between $\mathrm{V}_{2} \mathrm{O}_{5}$ in the slag and leached $\mathrm{V}$ has been found.

Vanadium oxides are usually associated to silicates and calcium-ferrite. Brownmillerite-type $\left(4 \mathrm{CaO} \cdot \mathrm{Al}_{2} \mathrm{O}_{3} \cdot \mathrm{Fe}_{2} \mathrm{O}_{3}\right)$ phases could also be formed with a low $\mathrm{Al}_{2} \mathrm{O}_{3}$ amount thanks to the 


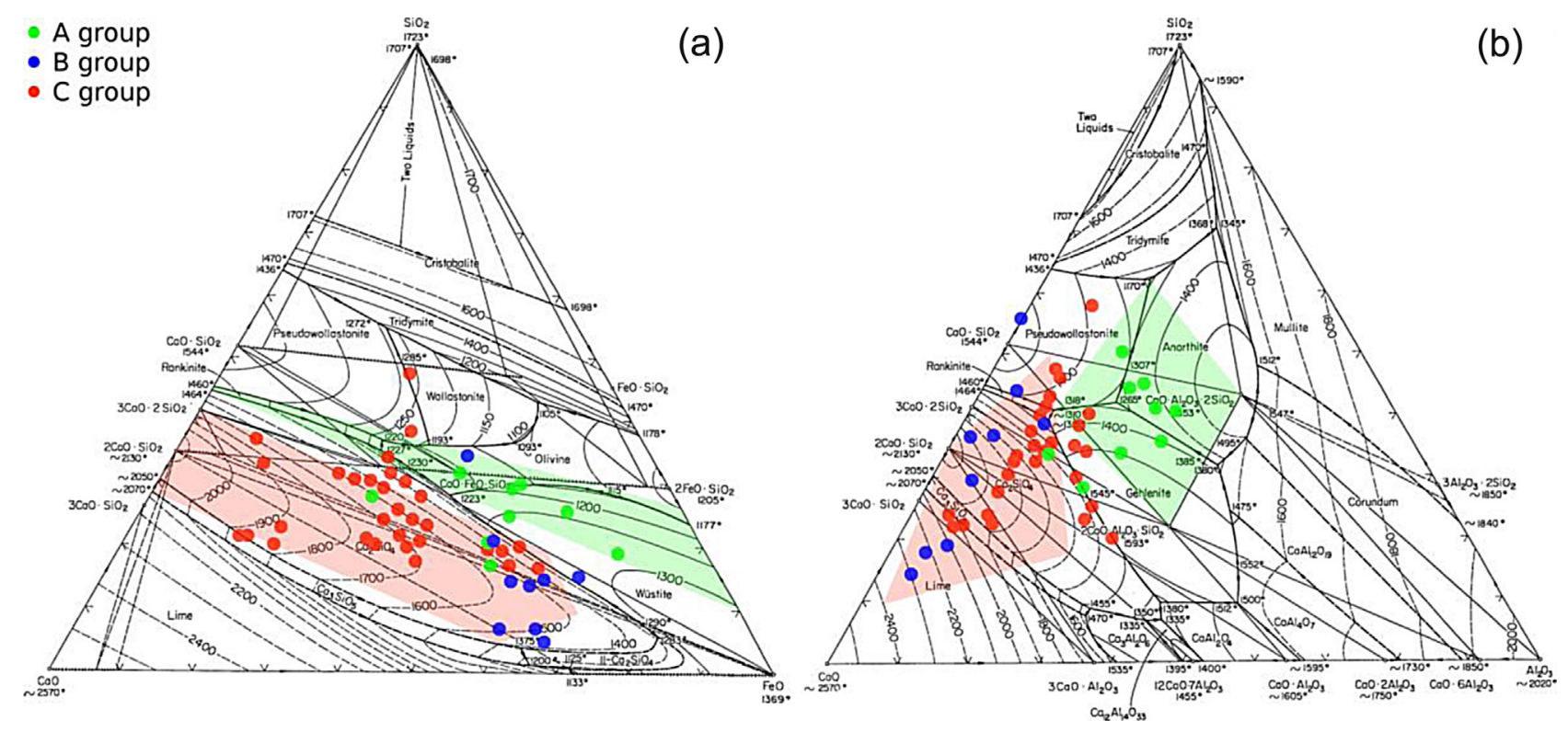

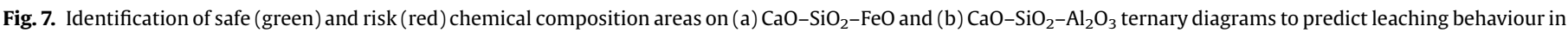

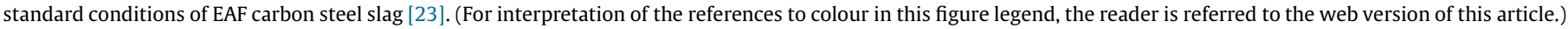

reaction between calcium-ferrite and vanadium and/or chromium oxide. Essentially, SEM-EDS investigations highlighted brownmillerite, constituted with high $\mathrm{V}$ and/or $\mathrm{Cr}$ oxide in place of $\mathrm{Al}_{2} \mathrm{O}_{3}$. For example, the brownmillerite identified in Fig. 4 is featured high $\mathrm{Cr}$ content (c.a. $9 \%$ at.) and non-negligible V content (c.a. $0.5 \%$ at.). In other samples, mainly belonging group $\mathrm{C}$, brownmillerite had a composition ranged from 0.5 to $1.0 \mathrm{~V}$ and $5-10 \mathrm{Cr}$ (\% at.). Since brownmillerite has hydraulic properties and hydrates during the first contact period between slag and water, in poor $\mathrm{Al}_{2} \mathrm{O}_{3}$ slag, higher $\mathrm{V}$ concentration can be eluted. In addition, $\mathrm{Al}$ and $\mathrm{Mg}$ oxides are the main constituents, together with magnetite, of spinel phases. The analysis carried out on the different slag samples investigated emphasized the vanadium tendency to also be bound in spinel phases. If the slag is featured by low content of $\mathrm{MgO}$ and $\mathrm{Al}_{2} \mathrm{O}_{3}$, non-stable spinels can occur, promoting $\mathrm{V}$ leaching. Furthermore, in these conditions, as demonstrated by Kuhn et al. [21,22], Cr can also be easily released.

High $\mathrm{MgO}$ content in the slag inhibit $\mathrm{V}$ leaching, but enhance $\mathrm{Ba}$ leaching. The above mentioned considerations may explain the conflicting behaviour between Ba and V. Effectively, group B slag manifested the release of $\mathrm{V}$ but not Ba. Their average chemical composition (reported in Table 3 ) is characterized by low $\mathrm{MgO}$ and $\mathrm{Al}_{2} \mathrm{O}_{3}$ content, that seem to favour $\mathrm{V}$ leaching. On the contrary, the slag characterized by higher $\mathrm{Al}_{2} \mathrm{O}_{3}$ and $\mathrm{MgO}$ content, indicated a higher Ba concentration in the leached solution. Moreover, for the slag featured by a higher $\mathrm{CaO}$ fraction, the $\mathrm{V}$ concentration in leachate solutions never reached worrying values, with an average concentration of less than $50 \mu \mathrm{g} / \mathrm{l}$ and limited data dispersion. On the other hand, slag featured by a low $\mathrm{CaO}$ concentration manifested $\mathrm{V}$ leaching, like the other cases. High $\mathrm{SiO}_{2}$ content in the slag seemed to improve its V-retaining behaviour (Fig. 6c). $\mathrm{SiO}_{2}$ over the $15 \%$ wt. seems to be enough to completely prevent $\mathrm{V}$ release. This result confirms the good V-retaining behaviour of acidic slag, as demonstrated in previous work [34,35].

Linear proportional dependence was instead retrieved between $\mathrm{V}_{2} \mathrm{O}_{5}, \mathrm{Cr}_{2} \mathrm{O}_{3}$ and leached $\mathrm{V}$ (Fig. 6d). The higher the $\mathrm{Cr}_{2} \mathrm{O}_{3}$, the higher the spinel fraction and size in the slag microstructure. High $\mathrm{Cr}_{2} \mathrm{O}_{3}$ content imposes the presence of higher spinel-forming species (i.e. $\mathrm{MgO}, \mathrm{Al}_{2} \mathrm{O}_{3}$ ) in order to ensure stable spinel formation $[21,22]$. If the slag chemical composition, does not allow for the spinel-forming species involved to be properly combined, unstable spinels are formed, inducing $\mathrm{Cr}$ and $\mathrm{V}$ leaching. The cooling rate and the cooling procedures also control the spinel formation $[12,18]$, but this type of correlation was not analysed in the present work.

\section{Chromium}

Concerning the $\mathrm{Cr}$ release behaviour, no indication or clear correlation were found between $\mathrm{Cr}$ concentration in the elute and slag chemical composition. Thus, as described by Kuhn et al. [21,22] the main factor ruling $\mathrm{Cr}$ immobilization is the formation of spinel structure with composition similar to natural $\mathrm{MgCr}_{2} \mathrm{O}_{4}$. Even if, nowadays, the only reliable forecasting tool to predict $\mathrm{Cr}$ leaching seems to be the sp-factor (Eq. (1)) proposed by Kuhn et al. [21,22], its efficacy has not been completely verified for carbon steel slag.

$$
\begin{aligned}
\text { sp }- \text { factor } & =0.2 \times \mathrm{MgO}+1.0 \times \mathrm{Al}_{2} \mathrm{O}_{3}+n \times \mathrm{FeO}_{n}-0.5 \\
& \times \mathrm{Cr}_{2} \mathrm{O}_{3}(\% \text { wt. })
\end{aligned}
$$

where $n$ is the optical electronegativity of iron ions, depends on the oxidation state of the EAF-slag and can assume a value of between 1 and 4 as a function of the oxidation number assumed by the Fe ions.

In fact, as reported in Fig. 6e, several samples that have an $s p$ factor over the $25 \%$ wt. (value considered enough to prevent $\mathrm{Cr}$ leaching). released $\mathrm{Cr}$, whereas some samples falling within the unsafe zone (between 5 and 25\% wt.), did not manifest any $\mathrm{Cr}$ leaching. It seems more reliable to focus on the effect of slag basicity (in terms of $\mathrm{CaO} / \mathrm{SiO}_{2}$ ratio) on $\mathrm{Cr}$ leaching (Fig. 6f). High slag basicity is associated with a high $\mathrm{Cr}^{6+} / \mathrm{Cr}^{3+}$ ratio [60]. Thus, increased slag basicity, decreases the $\mathrm{Cr}$ that can be bound in the spinel (in the $\mathrm{Cr}^{3+}$ form as $\mathrm{Cr}_{2} \mathrm{O}_{3}$ [60-62]), increasing the mean chromium content in the slag matrix. In addition, high basicity induces high $\mathrm{MgO}$ and $\mathrm{CaO}$ activity in the molten slag, resulting in the formation of a Ca-chromite phase instead of a more stable $\mathrm{MgCr}_{2} \mathrm{O}_{4}$ [63]. Ca-chromite is unstable and its role in $\mathrm{Cr}$ leaching is well known $[64,65]$.

The average slag chemical composition could help to predict slag properties, for both the leaching elements and microstructural features, since the relationship between these two aspects is 
established. In fact, the dangerous heavy metals involved in the leaching process from EAF carbon steel slag are controlled by the oxide species (i.e. $\mathrm{CaO}, \mathrm{MgO}, \ldots$ ) and specific crystalline phases (i.e. larnite, brownmillerite, ... ).

A useful indication about the chemical composition of safe solid slag is indicated in the ternary diagrams shown in Fig. 7. The slag fall in the green areas were featured by stable matrix, mainly formed by gehlenite and/or kirschsteinite and in most of the cases they were compliant with the leaching limits, whereas the slag fall in the red areas were characterized by larnite matrix and subjected to the release of polluting substances. Since the EAF slag can be considered a quinquenary oxide system, the effect of the other oxides species forming the slag (i.e. $\mathrm{Al}_{2} \mathrm{O}_{3}$ for $\mathrm{C}-\mathrm{F}-\mathrm{S}$ diagram and $\mathrm{MgO}$ for $\mathrm{C}-\mathrm{A}-\mathrm{S}$ ) can be determined by other pseudo-ternary diagrams for quaternary systems [66-70]. In particular, $\mathrm{Al}_{2} \mathrm{O}_{3}$ content over $5 \%$ by weight creates the formation of gehlenite and anorthite in the $\mathrm{CaO}-\mathrm{SiO}_{2}-\mathrm{FeO}$ system, closing the $\mathrm{CaO} \cdot \mathrm{SiO}_{2}$ fields. By increasing the $\mathrm{Al}_{2} \mathrm{O}_{3}$ concentration, however, the olivine field disappears [69,70]. On the contrary, $\mathrm{MgO}$ tends to close the gehlenite and anorthite filed in the $\mathrm{CaO}-\mathrm{SiO}_{2}-\mathrm{Al}_{2} \mathrm{O}_{3}$ system from $5 \%$ by weight. This aspect could explain why slag featured by a high concentration of $\mathrm{MgO}$ release high $\mathrm{Ba}$ concentration and form gehlenite structure with difficulty [66-68]. For example, the outliers of group A suffered this problem: even if their position on the $\mathrm{C}-\mathrm{A}-\mathrm{S}$ ternary diagram is in the field of gehlenite, their microstructure did not signal gehlenite. On the contrary, the matrix was characterized by high $\mathrm{Mg}$-di-calcium silicate, which induced the high Ba leaching highlighted during the standard leaching test.

Thus a correct balance of chemical composition could allow the formation of stable and safe slag. In particular, MgO should not exceed $5 \%$ by weight for high oxidized slag (groups $\mathrm{A}$ and $\mathrm{B}$ ) and the $7 \%$ for less oxidized ones (group C), whereas $\mathrm{Al}_{2} \mathrm{O}_{3}$ should be in the range $7-10 \%$ wt. Nonetheless, $\mathrm{CaO}$ should be controlled, to avoid reaching an overly high concentration that could stimulate $\mathrm{Cr}$ leaching and create dusting and volume instability problems.

Since the slag has to be prepared to obtain steels with the appropriate quality and properties, a thermo-chemical stabilization/inertization process (outside the EAF) should be applied independently on all the recyclable slag in order to avoid dangerous environmental contaminations. In particular, as proposed by Mombelli et al. [51] the addition of suitable external oxides during the deslagging operation could improve the sustainability of the slag, moving the chemical composition in the safe areas of ternary diagrams.

Even if water-slag interaction only interests the slag surface, it is enough to dissolve an important amount of dangerous substances and to drive the leachate $\mathrm{pH}$ to caustic values. These results, although qualitative, indicated that liquid-on-solid ratio plays a fundamental role on slag leaching behaviour. The characterization of the slag leaching behaviour through only standard leaching tests could be misleading in order to assess safety or hazard attitude of this by-product. If slags are to be used as unbound stone material, the continuous wetting-drying cycles may lead to dangerous substance accumulation into the environment even if the slag were declared safe after a standard elution test.

These considerations suggest that the characterization of slags should not only undergo the standard elution test but also a modified test in which the effect of liquid-on-solid ratio is investigated.

\section{Conclusions}

In this paper different EAF carbon steel slag associated to different steel production were investigated to understand the mechanisms that control the leaching of polluting substances during leaching tests in standard conditions. The slag chemical composition influences the leaching behaviour of the slag and thus, it can be used to forecast the outcome of leaching test.

On the basis of the obtained results, the following conclusions can be attained:

- slag characterized by high $\mathrm{CaO}$ and $\mathrm{MgO}$ content (although they indicated caustic leachate $\mathrm{pH}$ ) had better retaining behaviour against $\mathrm{V}$ release. Acidic slag (with high $\mathrm{SiO}_{2}$ content) was featured by a better trapping attitude against $\mathrm{V}$ release;

- high $\mathrm{CaO}$ and $\mathrm{MgO}$ concentrations lead to high Ba release. A correct balance of the basic oxide species could reduce the slag environmental impact, reducing the overall element leaching;

- high basicity slag, in terms of $\mathrm{CaO} / \mathrm{SiO}_{2}$ ratio, could enhance $\mathrm{Cr}$ leaching;

- water-slag interaction interests only the slag surface but was enough to dissolve important amounts of dangerous substances and to drive the leachate $\mathrm{pH}$ to caustic values;

- ternary diagrams can be used to predict the leaching behaviour of slag but the effect of other oxides on ternary systems must be taken into account due to their significant effects on phase equilibrium;

- a correct balance of chemical composition could allow the formation of stable and safe slag, eventually providing opportune chemical correction outside the EAF.

In order to satisfactorily reuse EAF slag for civil purposes (aggregates for asphalt, inert gravel, ... ) some practical recommendations can be highlighted: MgO should not exceed $5 \%$ by weight for high oxidized slag and the $7 \%$ for less oxidized ones, $\mathrm{Al}_{2} \mathrm{O}_{3}$ should be in the range $7-10 \% \mathrm{wt}$. and $\mathrm{CaO}$ should not exceed the $30 \%$ by weight to fit the safe areas on ternary diagrams.

If the slag chemical composition is out the recommended range, a chemical composition correction by the addition of stabilizers (i.e. $\mathrm{SiO}_{2}, \mathrm{Al}_{2} \mathrm{O}_{3}, \ldots$ ) would be applied outside the EAF. Slag characterized by stable and non-leachable microstructure can be safely used also in unbound applications, namely unpaved roads, armourstone or gabions.

\section{Appendix A}

List of phases.

\begin{tabular}{|c|c|c|}
\hline Phase & Definition & Formula \\
\hline Akermanite & Calcium-magnesium silicate & $\begin{array}{l}\mathrm{Ca}_{2} \mathrm{MgSi}_{2} \mathrm{O}_{7} \\
\left(2 \mathrm{CaO} \cdot \mathrm{MgO} \cdot 2 \mathrm{SiO}_{2}\right)\end{array}$ \\
\hline Anorthite & Calcium-aluminium silicate & $\mathrm{CaAl}_{2} \mathrm{Si}_{2} \mathrm{O}_{8}\left(\mathrm{CaO} \cdot \mathrm{Al}_{2} \mathrm{O}_{3} \cdot 2 \mathrm{SiO}_{2}\right)$ \\
\hline Bredigite & $\alpha$ di-calcium silicate & $\begin{array}{l}\mathrm{Ca}_{7} \mathrm{Mg}\left(\mathrm{SiO}_{4}\right)_{4} \\
\left(7 \mathrm{CaO} \cdot \mathrm{MgO} \cdot 4 \mathrm{SiO}_{2}\right)\end{array}$ \\
\hline Brownmillerite & $\begin{array}{l}\text { Tetra-calcium aluminate } \\
\text { ferrite }\end{array}$ & $\begin{array}{l}\mathrm{Ca}_{2}(\mathrm{Al}, \mathrm{Fe})_{2} \mathrm{O}_{5} \\
\left(4 \mathrm{CaO} \cdot \mathrm{Al}_{2} \mathrm{O}_{3} \cdot \mathrm{Fe}_{2} \mathrm{O}_{3}\right)\end{array}$ \\
\hline Gehlenite & Calcium-aluminium silicate & $\begin{array}{l}\mathrm{Ca}_{2} \mathrm{Al}(\mathrm{AlSi}) \mathrm{O}_{7} \\
\left(2 \mathrm{CaO} \cdot \mathrm{Al}_{2} \mathrm{O}_{3} \cdot \mathrm{SiO}_{2}\right)\end{array}$ \\
\hline Kirschsteinite & Calcium olivine & $\mathrm{CaFeSiO}_{4}\left(\mathrm{CaO} \cdot \mathrm{FeO} \cdot \mathrm{SiO}_{2}\right)$ \\
\hline Larnite & $\beta$ or $\gamma$ di-calcium silicate & $\mathrm{Ca}_{2} \mathrm{SiO}_{4}\left(2 \mathrm{CaO} \cdot \mathrm{SiO}_{2}\right)$ \\
\hline Mayenite & Calcium aluminate & $\mathrm{Ca}_{12} \mathrm{Al}_{14} \mathrm{O}_{33}\left(12 \mathrm{CaO} \cdot 7 \mathrm{Al}_{2} \mathrm{O}_{3}\right)$ \\
\hline $\mathrm{Mg}$-Cr-spinel & Magnesiochromite (spinel) & $\mathrm{MgCr}_{2} \mathrm{O}_{4} /(\mathrm{Mg}, \mathrm{Fe})(\mathrm{Al}, \mathrm{Cr})_{2} \mathrm{O}_{4}$ \\
\hline Wustite & Iron oxide & $(\mathrm{Fe}, \mathrm{Mg}, \mathrm{Mn}) \mathrm{O} / \mathrm{MgO}^{-} \mathrm{FeO}$ \\
\hline
\end{tabular}

\section{References}

[1] G. Ye, E. Burstroem, A.M. Faellman, Utilisation and stabilisation of steelmaking slags, Swedish Waste Research Council, Stockholm, 1995, pp. 57 AFR-Report.

[2] International Programme on Chemical Safety, Inter-Organization Programme for the Sound Management of Chemicals. Inorganic chromium(VI) compounds. Concise international chemical assessment document, n. 78. World Health Organization, Geneve (CH), 2013. 
[3] World Health Organization, International Programme on Chemical Safety Barium: health and safety guide, n. 46. World Health Organization, Geneve (CH), 1991.

[4] World Health Organization, International Programme on Chemical Safety. Vanadium and some vanadium salts: health and safety guide, n. 42 . World Health Organization, Geneve (CH), 1990.

[5] B.B. Lind, A.-M. Fällman, L.B. Larsson, Environmental impact of ferrochrome slag in road construction, Waste Manage. 21 (3)(2001) 255-264, doi:http://dx. doi.org/10.1016/S0956-053X(00)00098-2.

[6] P. Chaurand, J. Rose, V. Briois, L. Olivi, J. Hazemann, O. Proux, J. Domas, J. Bottero, Environmental impacts of steel slag reused in road construction: a crystallographic and molecular (XANES) approach, J. Hazard. Mater. 139 (3) (2007) 537-542, doi:http://dx.doi.org/10.1016/j.jhazmat.2006.02.060.

[7] A. Van Zomeren, S.R. van der Laan, H.B.A. Kobesen, W.J.J. Huijgen, R.N.J Comans, Changes in mineralogical and leaching properties of converter stee slag resulting from accelerated carbonation at low $\mathrm{CO}_{2}$ pressure, Waste Manage. 31 (11) (2011) 2236-2244, doi:http://dx.doi.org/10.1016/j.was man.2011.05.022.

[8] C.J. Engelsen, H.A. van der Sloot, G. Wibetoe, H. Justnes, W. Lund, E. Stoltenberg-Hansson, Leaching characterisation and geochemical modelling of minor and trace elements released from recycled concrete aggregates, Cem. Concr. Res. 40 (12) (2010) 1639-1649, doi:http://dx.doi.org/10.1016/j.cemconres.2010.08.001.

[9] C.J. Engelsen, G. Wibetoe, H.A. van der Sloot, W. Lund, G. Petkovic, Field site leaching from recycled concrete aggregates applied as sub-base material in road construction, Sci. Total Environ. 427-428 (2012) 86-97, doi:http://dx.doi. org/10.1016/j.scitotenv.2012.04.021.

[10] Italian Ministerial Decree, D.M. 03 August 2005 N. 201: definition of the criteria for waste acceptance at landfills.

[11] Italian Ministerial Decree, D.M. 05 April 2006 N. 186: identification of nonhazardous waste subject to simplified recovery procedures.

[12] Forschungsgesellschaft für Straßen- und Verkehrswesen, Arbeitsgruppe Gesteinskörnungen, Ungebundene Bauweisen, Technische Lieferbedingungen für Baustoffgemische und Boden zur Herstellung von Schichten ohne Bindemittel im Straßenbau (TL G SoB-StB 04), Ausgabe 2004/Fassung 2007.

[13] Service d'Etudes sur les Transports, les Routes et leurs Aménagements (SETRA), Acceptabilité environnementale de matériaux alternatifs en technique routière-Les laitiers sidérurgiques, 10/10/2012, ISBN 978-2-11-1298811.

[14] Basque Country Ministerial Decree, RD 34/2003, Disposiciones generales departamento de ordenación del territorio y medio ambiente $n^{\circ} 1186$, decreto 34/2003, de 18 de febrero.

[15] Basque Country Ministerial Decree, RD 49/2009, Disposiciones generales departamento de ordenación del territorio y medio ambiente $n^{\circ} 1524$, decreto 49/2009, de 24 de febrero.

[16] Assessing legal compliance with and implementation of the waste acceptance criteria and procedures by the eu-15, 07.0307/2008/510910/SER/G4, European Commission, Brussels, 2009.

[17] H. Saveyn, P. Eder, E. Garbarino, L. Muchova, O. Hjelmar, H. van der Sloot, R Comans, A. van Zomeren, J. Hyks, A. Oberender, Study on Methodological Aspects regarding Limit Values for Pollutants in Aggregates in the Context of the Possible Development of End-Of-Waste Criteria under the EU Waste Framework Directive, Publications Office of the European Union, Luxembourg, 2014.

[18] A.M. Faellman, J. Hartlén, Utilisation of electric arc furnace slag in road construction, in: M. Kamon (Ed.), Environmental Geotechnics, Balkema, Rotterdam, 1996, pp. 703-708.

[19] V. Arredondo-Torres, A. Romero-Serrano, B. Zeifert, J. Cruz-Rivera, P. FloresSánchez, A. Cruz-Ramírez, Stabilization of $\mathrm{MgCr}_{2} \mathrm{O}_{4}$ spinel in slags of the $\mathrm{SiO}_{2}$ $\mathrm{CaO}-\mathrm{MgO}-\mathrm{Cr}_{2} \mathrm{O}_{3}$ system, Rev. Metal. 42-6 (2006) 417-424.

[20] K. Shinoda, H. Hatakeda, N. Maruoka, H. Shibata, S. Kitamura, S. Suzuki, Chemical state of chromium in $\mathrm{CaO}-\mathrm{SiO}_{2}$ base oxides annealed under different conditions, ISIJ Int. 48-10 (2008) 1404-1408, doi:http://dx.doi.org/10.2355/ isijinternational.48.1404.

[21] M. Kuhn, D. Mudersbach, J.M. Baena Liberato, V. De Angelis, D. Capodilupo, U. De Fries, Chrome Immobilization in EAF Slag from High Alloy SteelmakingDevelopment of a Slag Treatment Process, Office for Official Publications of European Communities, Luxembourg, 2006 Project 7215-PP/044.

[22] D. Mudersbach, M. Kuhn, J. Geiseler, K. Koch, Chrome immobilisation in EAFslags from high-alloy steelmaking: tests at FEhS-institute and development of an operational slag treatment process, Proceedings of the 1st Interntational Slag Valorisation Symposium, Leuven (Belgium), 6-7 April 2009, 2015, pp. $101-110$.

[23] E.M. Levin, C.E. Robbins, H.F. McMurdie, Phase Diagrams for Ceramist, Vol. 1, American Ceramic Society, Columbus (OH), 1964.

[24] M. Tossavainen, F. Engstrom, Q. Yang, N. Menad, M. Lidstrom Larsson, B. Bjorkman, Characteristics of steel slag under different cooling conditions, Waste Manage. 27 (10) (2007) 1335-1344, doi:http://dx.doi.org/10.1016/j. wasman.2006.08.002.

[25] H. Shen, E. Forssberg, U. Nordström, Physicochemical and mineralogical properties of stainless steel slags oriented to metal recovery, Resour. Conserv. Recy. 40 (3) (2004) 245-271, doi:http://dx.doi.org/10.1016/S0921-3449(03) 00072-7.

[26] C. Shi, Steel slag - its production, processing, characteristics, and cementitious properties, J. Mater. Civ. Eng. 16 (3) (2004) 230-236, doi:http://dx.doi.org/ 10.1061/(ASCE)0899-1561(2004)16:3230.
[27] M.P. Luxán, R. Sotolongo, F. Dorrego, E. Herrero, Characteristics of the slags produced in the fusion of scrap steel by electric arc furnace, Cem. Concr. Res. 30 (4) (2000) 517-519, doi:http://dx.doi.org/10.1016/S0008-8846(99)00253-7.

[28] P.E. Tsakiridis, G.D. Papadimitriou, S. Tsivilis, C. Koroneos, Utilization of steel slag for Portland cement clinker production, J. Hazard. Mater. 152 (2) (2008) 805-811, doi:http://dx.doi.org/10.1016/j.jhazmat.2007.07.093.

[29] L.M. Juckes, The volume stability of modern steelmaking slags, Miner. Process. Extr. Metall. 112 (2003) 177-197.

[30] A.S. Reddy, R.K. Pradhan, S. Chandra, Utilization of basic oxygen furnace (BOF) slag in the production of a hydraulic cement binder, Int. J. Miner. Process. 79 (2) (2006) 98-105, doi:http://dx.doi.org/10.1016/j.minpro.2006.01.001.

[31] M. Nicolae, I. Vilciu, F. Zaman, X-ray diffraction analysis of steel slag and blast furnace slag viewing their use for road construction, UPB Sci. Bull. Ser. B 69-2 (2007) 99-108.

[32] G.R. Qian, D.D. Sun, J.H. Tay, Z.Y. Lai, Hydrothermal reaction and autoclave stability of Mg bearing RO phase in steel slag, Br. Ceram. Trans. 101 (4) (2002) 159-164, doi:http://dx.doi.org/10.1179/096797802225003415.

[33] J.M. Manso, M. Losañez, J.A. Polanco, J.J. Gonzalez, Ladle furnace slag in construction, J. Mater. Civ. Eng. 17 (5) (2005) 513-518, doi:http://dx.doi.org/ 10.1061/(ASCE)0899-1561(2005)17:5513.

[34] J. Geiseler, Use of steelworks slag in Europe, Waste Manage. 16 (1-3) (1996) 59-63, doi:http://dx.doi.org/10.1016/S0956-053X(96)00070-0.

[35] F. Wachsmuth, J. Geiseler, W. Fix, K. Koch, K. Schwerdtfeger, Contribution to the structure of BOF-slags and its influence on their volume stability, Can. Metall. Q. 20 (3) (1981) 279-284, doi:http://dx.doi.org/10.1179/cmq.1981.20.3.279.

[36] G. Qian, D.D. Sun, J.H. Tay, Z. Lai, G. Xu, Autoclave properties of kirschsteinitebased steel slag, Cem. Concr. Res. 32 (9) (2002) 1377-1382, doi:http://dx.doi. org/10.1016/S0008-8846(02)00790-1.

[37] Indipendet Evironmental Technical Evaluation Group (IETEG), Chromium (VI) Handbook, CRC Press, Baton Rouge (LA), 2004.

[38] S. Barella, A. Gruttadauria, F. Magni, C. Mapelli, D. Mombelli, Survey about safe and reliable use of EAF slag, ISIJ Int. 52 (12) (2012) 2295-2302, doi:http://dx. doi.org/10.2355/isijinternational.52.2295.

[39] D. Mombelli, C. Mapelli, A. Gruttadauria, C. Baldizzone, F. Magni, P.L. Levrangi, P. Simone, Analysis of electric arc furnace slag, Steel Res. Int. 83-11 (2012) 1012-1019.

[40] D. Mombelli, C. Mapelli, A. Gruttadauria, C. Baldizzone, F. Magni, P.L. Levrangi, P. Simone, Micro-structural and chemical characterization of electric arc furnace slag, Yejin Fenxi/Metall. Anal. 32-3 (2012) 7-13.

[41] J.R. Young, M.J. How, A.P. Walker, W.M.H. Worth, Classification as corrosive or irritant to skin of preparations containing acidic or alkaline substances, without testing on animals, Toxicol. Vitro 2 (1) (1988) 19-26, doi:http://dx.doi. org/10.1016/0887-2333(88)90032-X.

[42] D. Yoon, B.I. Lee, P. Badheka, X. Wang, Barium ion leaching from barium titanate powder in water, J. Mater. Sci. 14 (2003) 165-169.

[43] E. Bordes-Richard, P. Courtine, Metal Oxides: Chemistry and Application Chapter 10, CRC Press, Boca Raton (FL), 2006.

[44] V. Dimitrov, T. Komatsu, An interpretation of optical properties of oxides and oxide glasses in terms of the electronic ion polarizability and average single bond strength, J. Univ. Chem. Technol. Metall. 45-3 (2010) 219-250.

[45] P. Chaurand, J. Rose, V. Briois, L. Olivi, J.L. Hazemann, O. Proux, J. Domas, J.Y. Bottero, Environmental impacts of steel slag reused in road construction: A crystallographic and molecular (XANES) approach, J. Hazard. Mater. 139 (3) (2007) 537-542, doi:http://dx.doi.org/10.1016/j.jhazmat.2006.02.060.

[46] A. van Zomeren, S.R. van der Laan, H.B.A. Kobesen, W.J.J. Huijgen, R.N.J. Comans, Changes in mineralogical and leaching properties of converter steel slag resulting from accelerated carbonation at low $\mathrm{CO}_{2}$ pressure, Waste Manage. 31 (11) (2011) 2236-2244, doi:http://dx.doi.org/10.1016/j.wasman.2011.05.022.

[47] H.F.W. Taylor, Cement Chemistry, Academic Press, London, UK, 1990, pp. 3839.

[48] J. Pera, A. Amrouz, Development of highly reactive metakaoline from paper sludge, advances in cement based, Materials 7 (1998) 49-56.

[49] A. Arper, Phase Diagram 6-II: Materials Science and Technology, Vol. 2, Elsevier, Amsterdam, The Netherlands, 2012, pp. 158.

[50] A.R. West, Solid State Chemistry and Its Applications, John Wiley \& Sons, Hoboken (NJ), 1987.

[51] D. Mombelli, C. Mapelli, S. Barella, A. Gruttadauria, G. Le Saout, E. Garcia-Diaz, The efficiency of quartz addition on electric arc furnace (EAF) carbon steel slag stability, J. Hazard. Mater. 279 (2014) 586-596, doi:http://dx.doi.org/10.1016/j. jhazmat.2014.07.045.

[52] M. Gelfi, G. Cornacchia, R. Roberti, Investigations on leaching behavior of EAF steel slags, 6th European Slag Conference EUROSLAG 2010, Madrid (Spain), 2015, pp. $157-169$

[53] F. Engström, M.L. Larsson, C. Samuelsson, Å Sandström, R. Robinson, B. Björkman, Leaching behavior of aged steel slags, Steel Res. Int. 85 (4) (2014) 607-615, doi:http://dx.doi.org/10.1002/srin.201300119.

[54] R. Baciocchi, G. Costa, A. Polettini, R. Pomi, Effects of thin-film accelerated carbonation on steel slag leaching, J. Hazard. Mater. 286 (2015) 369-378, doi: http://dx.doi.org/10.1016/j.jhazmat.2014.12.059.

[55] E. Belhadj, C. Diliberto, A. Lecomte, Characterization and activation of basic oxygen furnace slag, Cem. Concr. Comput. 34 (1) (2012) 34-40, doi:http://dx. doi.org/10.1016/j.cemconcomp.2011.08.012.

[56] C.E. Tilley, The occurrence of an orthorhombic high-temperature form of $\mathrm{Ca}_{2} \mathrm{SiO}_{4}$ (Bredigite) in the scawt hill contact-zone and as a constituent of slags, 
Mineral. Mag. 28 (200) (1948) 255-271, doi:http://dx.doi.org/10.1180/minmag.1948.028.200.02.

[57] Forschungszentrum Karlsruhe Umweltforschungszentrum Contaminated Soil Vol. 2, Proceedings of Seventh International FZK/TNO Conference on Contaminated Soil, Leipzig (Germany) September 2000, 2000.

[58] G.C. Lai, T. Nojiri, K.I. Nakano, Studies of the stability of $\beta-\mathrm{Ca}_{2} \mathrm{SiO}_{4}$ doped by minor ions, Cem. Concr. Res. 22 (5) (1992) 743-754, doi:http://dx.doi.org/ 10.1016/0008-8846(92)90097-F.

[59] F. Xiuji, L. Shizong, Investigation of the effect of minor ions on the stability of $\beta-C_{2} S$ and the mechanism of stabilization, Cem. Concr. Res. 16 (4) (1986) 587601, doi:http://dx.doi.org/10.1016/0008-8846(86)90097-9.

[60] N. Sano, Reduction of Chromium Oxide in Stainless Steel Slags, Proceedings: 10th International Ferroalloys Congress (2004) .

[61] K. Moritai, T. Shibuya, N. Sano, Solubility of the chromite in $\mathrm{MgO}-\mathrm{Al}_{2} \mathrm{O}_{3}-\mathrm{SiO}_{2}-$ $\mathrm{CaO}$ melts at $1600^{\circ} \mathrm{C}$ in air, Tetsu Hagane 74-4 (1988) 632-639.

[62] K. Morita, A. Inoue, N. Takayama, N. Sano, Solubility of MgO·Cr2O3 in MgO$\mathrm{Al}_{2} \mathrm{O}_{3}-\mathrm{SiO}_{2}-\mathrm{CaO}$ slag at $1600^{\circ} \mathrm{C}$ under reducing conditions, Tetsu Hagane $74-6$ (1988) 999-1005.

[63] G.J. Albertsson, Abatement of Chromium Emissions from Steelmaking SlagsCr Stabilization by Phase Separation, Doctoral Thesis, Department of Material Science and Engineering, Royal Institute of Technology, Stockholm (Sweden), 2015.
[64] J. Ylipekkala, Quality Management of Chromium Containing Steel Slags from Melt Phase to Cooling, Master Thesis, Department of Chemical Engineering and Geosciences. Division of Process Metallurgy. Luleå University of Technology, Luleå (Sweden), 2015.

[65] Selected solubility products and formation constants, at $25^{\circ} \mathrm{C}$. Available from: http://chemistry.csudh.edu/oliver/chemdata/data-ksp.htmi, last updated 1997.

[66] Verein Deutscher Eisenhuttenleute, Slag Atlas, 2nd edition, Verlag Stahleisen GmbH, Dusseldorf (Germany), 1981.

[67] H.-C. Chuang, W.-S. Hwang, S.-H. Liu, Effects of graphite, $\mathrm{SiO}_{2}$, and $\mathrm{Fe}_{2} \mathrm{O}_{3}$ on the crushing strength of direct reduced iron from the Carbothermic reduction of residual materials, Mater. Trans. 51 (3) (2010) 488-495, doi:http://dx.doi.org/ 10.2320/matertrans.M2009299.

[68] H. Chuang, W. Hwang, S. Liu, Effects of basicity and FeO content on the softening and melting temperatures of the $\mathrm{CaO}-\mathrm{SiO}_{2}-\mathrm{MgO}-\mathrm{Al}_{2} \mathrm{O}_{3}$ slag system, Mater. Trans. 50 (6) (2009) 1448-1456, doi:http://dx.doi.org/10.2320/matertrans.MRA2008372.

[69] A. Kondratiev, E. Jak, Predicting coal ash slag flow characteristics (viscosity model in the $\mathrm{Al}_{2} \mathrm{O}_{3}-\mathrm{CaO}-$ "FeO"- $\mathrm{SiO}_{2}$ system), Fuel 80-14 (2001) 1989-2000.

[70] I.-H. Jung, Overview of the applications of thermodynamic databases to steelmaking processes, Calphad 34 (3) (2010) 332-362, doi:http://dx.doi.org/ 10.1016/j.calphad.2010.06.003. 